\title{
Increased Thresholds for Long-Term Potentiation and Contextual Learning in Mice Lacking the NMDA-type Glutamate Receptor $\epsilon 1$ Subunit
}

\author{
Yuji Kiyama, ${ }^{1}$ Toshiya Manabe, ${ }^{2}$ Kenji Sakimura, ${ }^{3,4}$ Fumiko Kawakami, ${ }^{2}$ Hisashi Mori, ${ }^{1}$ and \\ Masayoshi Mishina ${ }^{1,4}$
}

Departments of ${ }^{1}$ Molecular Neurobiology and Pharmacology and ${ }^{2}$ Neurophysiology, School of Medicine, University of Tokyo, Tokyo 113-0033, Japan, 32Department of Cellular Neurobiology, Brain Research Institute, Niigata University, Niigata 951-8585, Japan, and ${ }^{4}$ Core Research for Evolutional Science and Technology, Japan Science and Technology

Corporation, Saitama 332-0012, Japan

The NMDA-type glutamate receptor (GluR) channel, composed of the GluR $\epsilon$ and $\mathrm{GluR} \zeta$ subunits, plays a key role in synaptic plasticity in the CNS. The mutant mice lacking the GluRe1 subunit exhibited a reduction in hippocampal long-term potentiation (LTP), but a stronger tetanic stimulation restored the impairment and the saturation level of LTP was unaltered. These results suggest an increase of threshold for LTP induction in the GluR $\epsilon 1$ mutant mice. After a series of backcrosses we established a GluR $\epsilon 1$ mutant mouse line with a $99.99 \%$ pure C57BL/6 genetic background. The performance of the mutant mice in tone- and context-dependent fear conditioning tests was comparable with that of the wild-type mice. However, a significant difference in the extent of contextual learning be- came apparent when the chamber exposure time before footshock was shortened. Furthermore, there was a significant difference in freezing responses immediately after footshock on the conditioning day between the wild-type and mutant mice, and the difference was not restored by longer chamber exposure in contrast to the contextual learning on the next day of the conditioning. These results suggest that the GluRe1 subunit of the NMDA receptor channel is a determinant of thresholds for both hippocampal LTP and contextual learning and plays differential roles in two forms of contextual fear memories.

Key words: NMDA receptor channel; GluRe1 subunit; contextual learning; fear conditioning; LTP; threshold; memory; hippocampus
The NMDA subtype of the glutamate receptor (GluR) channel plays roles in synaptic plasticity as a molecular coincidence detector (Bliss and Collingridge, 1993; Malenka and Nicoll, 1993). Studies with selective antagonists have revealed diverse physiological roles of NMDA receptor channels in learning, memory, and neural development (Morris et al., 1986; Cline et al., 1987; Kleinschmidt et al., 1987). NMDA receptor channels are composed of the GluR $\epsilon$ (NR2) and GluR $\zeta(\mathrm{NR} 1)$ subunits. There are four GluR $\epsilon$ subunit genes (Ikeda et al., 1992; Kutsuwada et al., 1992; Meguro et al., 1992; Monyer et al., 1992; Nagasawa et al., 1996), although GluR $\zeta$ subunit variants are derived from a single gene (Moriyoshi et al., 1991; Yamazaki et al., 1992; Hollmann et al., 1993). The molecular composition of NMDA receptor channels varies, depending on brain regions and developmental stages (Watanabe et al., 1992). The four GluR $\epsilon$ subunits are also distinct in functional properties and regulations (Seeburg, 1993; Mori and Mishina, 1995). Thus, multiple GluR $\epsilon$ subunits are key determinants of the NMDA receptor channel diversity.

The physiological significance of the molecular diversity of the

\footnotetext{
Received April 29, 1998; revised June 15, 1998; accepted June 17, 1998.

This work was supported by research grants from Core Research for Evolutional Science and Technology of Japan Science and Technology Corporation, the Ministry of Education, Science, Sports, and Culture of Japan, and the Asahi Glass Foundation. We thank Dr. T. Takahashi for advice and encouragement; Mses. R. Natsume, Y. Asaka, M. Yoshida, and M. Furuya for help in breeding mice; and Ms. M. Senbonmatsu for help in the preparation of this manuscript.

Correspondence should be addressed to Dr. Masayoshi Mishina, Department of Molecular Neurobiology and Pharmacology, School of Medicine, University of Tokyo, Hongo 7-3-1, Bunkyo-ku, Tokyo 113-0033, Japan.

Copyright (C) 1998 Society for Neuroscience $\quad 0270-6474 / 98 / 186704-09 \$ 05.00 / 0$
}

NMDA receptor channel has been examined by gene-targeting techniques. We showed that disruption of the GluR $\epsilon 1$ (NR2A) gene resulted in the reduction of hippocampal long-term potentiation (LTP) and impairment of Morris water maze learning (Sakimura et al., 1995). GluRe2 (NR2B) mutant mice died shortly after birth and failed to form the whisker-related neural pattern (barrelettes) in the brainstem trigeminal complex (Kutsuwada et al., 1996), similar to GluR $\zeta 1$ (NR1) mutant mice (Forrest et al., 1994; Li et al., 1994). The ablation of the GluRe2 subunit also impaired synaptic plasticity in the hippocampus (Kutsuwada et al., 1996; Ito et al., 1997). GluR $\epsilon 4$ (NR2D) mutant mice exhibited reduced spontaneous behavioral activity (Ikeda et al., 1995), whereas GluRe3 (NR2C) mutant mice showed little obvious deficit (Ebralidze et al., 1996; Kadotani et al., 1996; Sprengel et al., 1998). These analyses suggest that the GluR $\epsilon 1$ and GluRe2 subunits play important roles in development, synaptic plasticity, learning, and memory. By intraventricular infusion of D-2-amino-5-phosphonovalerate (APV), Morris et al. (1986) first suggested a link between hippocampal LTP and spatial learning. Recently, Tsien et al. (1996) showed by a region-specific gene targeting that the NMDA receptor channel in the hippocampal CA1 region was essential for LTP and spatial learning. However, NMDA receptor channel-dependent hippocampal LTP may not be essential for spatial memory itself, although required for some component of water maze learning, because pretraining eliminated the APV inhibition (Bannerman et al., 1995; Saucier and Cain, 1995). In the present investigation we used fear conditioning, a rapidly acquired and persistent form of simple associative learning (Fanselow, 1980, 1984), to investigate the role of the 
GluR $\epsilon 1$ subunit in learning and memory. The genetic background of the GluR $\epsilon 1$ mutant mice that were used was highly homogeneous after a series of backcrosses. Furthermore, we characterized the impairment of hippocampal LTP in GluR $\epsilon 1$ mutant mice.

\section{MATERIALS AND METHODS}

Animals. C57BL/6 and CBA mice were purchased from Clea (Tokyo, Japan) and Charles River (Yokohama, Japan), respectively. The mutant mouse lacking the GluR $\epsilon 1$ subunit of the NMDA receptor channel was produced by homologous recombination in TT2 embryonic stem (ES) cells derived from C57BL $/ 6 \times$ CBA mouse, using a targeting vector composed of the GluR $\epsilon 1$ subunit gene from C57BL/6 mouse as described (Sakimura et al., 1995). The chimeric mouse derived from the recombinant ES cells was crossed to C57BL/6 mouse to yield heteromeric F2 mice with a $75 \%$ pure $\mathrm{C} 57 \mathrm{BL} / 6$ genetic background. Heterozygous mice for the GluR $\epsilon 1$ subunit gene were crossed successively to C57BL/6 mice to yield next generations with a purer C57BL/6 genetic background. The F13 heterozygous mice were crossed to each other to yield the homozygous GluR $\epsilon 1$ subunit mutant mice $(-/-)$ with a $99.99 \%$ pure C57BL/6 genetic background and the wild-type littermates $(+/+)$. The genotypes of mice were determined by tail biopsy and PCR, using primers E1P1, 5'-TCTGGGGCCTGGTCTTCAACAATTCTGTGC-3' (the nucleotide residues 1766-1795 of GluR $\epsilon 1$ cDNA; Meguro et al., 1992), E1P2, 5'-CTTCTTGTCACTGAGGCCAGTCACTTGGTC-3' (complementary to the residues 1921-1950), and NeoP1, 5'-GCCTGCTTGCCGAA TATCATGGTGGAAAAT-3'. Southern blot hybridization analysis of the genomic DNA was performed by using the $1.2 \mathrm{~kb} S m a \mathrm{I}$ fragment from GluR $\epsilon 1$ genomic DNA (probe A) as described (Sakimura et al., 1995). Animal care was performed in accordance with institutional guidelines. Mice were fed ad libitum with standard laboratory chow and water in standard animal cages under a $12 \mathrm{hr}$ light/dark cycle. Electrophysiological and behavioral analyses of mice were done in a blind manner.

Electrophysiology. The wild-type and GluR $\epsilon 1$ mutant F2 mice 9-17 weeks old were decapitated under halothane anesthesia, and hippocampi were removed quickly. Transverse hippocampal slices $(400 \mu \mathrm{m})$ were cut with a vibratome tissue slicer and placed in a holding chamber for at least $1 \mathrm{hr}$. Then a single slice was transferred to a recording chamber and submerged beneath a continuously perfusing medium that had been saturated with $95 \% \mathrm{O}_{2} / 5 \% \mathrm{CO}_{2}$. The medium contained (in $\mathrm{mM}$ ) 119 $\mathrm{NaCl}, 2.5 \mathrm{KCl}, 1.3 \mathrm{MgSO}_{4}, 2.5 \mathrm{CaCl}_{2}, 1.0 \mathrm{NaH}_{2} \mathrm{PO}_{4}, 26.2 \mathrm{NaHCO}_{3}$, and 11 glucose plus $0.1 \mu \mathrm{M}$ picrotoxin. All experiments were performed at room temperature $\left(22-25^{\circ} \mathrm{C}\right)$. Recordings were made in the hippocampal CA1 region, using an Axopatch 1D amplifier with a glass pipette filled with $3 \mathrm{M} \mathrm{NaCl}$. Field EPSPs (fEPSPs) were evoked by stimulating Schaffer collateral/commissural fibers in the stratum radiatum at $0.1 \mathrm{~Hz}$ with a bipolar tungsten stimulating electrode and were analyzed and stored on an IBM-compatible personal computer. The stimulus strength was adjusted to give initial EPSP slopes of $0.15-0.20 \mathrm{mV} / \mathrm{msec}$ (defined as the "standard" stimulus strength in this paper) unless otherwise stated. LTP was induced by high-frequency stimulation $(100 \mathrm{~Hz}$ for $1 \mathrm{sec}$, a single train). In two-pathway recordings the independence of the two pathways was determined by the lack of paired-pulse facilitation between them. When the stimulus strength was increased, independence was examined as above just before tetanic stimulation was applied to that pathway. Furthermore, when we applied tetanic stimulation in one pathway, we did not observe post-tetanic potentiation in the other pathway in any experiments, indicating that the two pathways were independent.

Fear conditioning. For behavioral analyses we used F13 GluR $\epsilon 1$ mutant mice and their littermate wild-type mice from postnatal day 35 (P35) to P48. The average body weights were $16.9 \pm 0.2$ gm (mean \pm SEM; $n=$ 104) for the wild-type mice and $16.2 \pm 0.2 \mathrm{gm}(n=162)$ for the mutant mice. Naive adult mice were housed individually for at least 1 week before behavioral testing and were handled for $1 \mathrm{~min}$ every day to reduce stress. Fear conditioning was conducted in a small rodent chamber $(10 \times$ $10 \times 10 \mathrm{~cm}$ ) with clear polyvinyl chloride boards and a stainless steel rod floor (CL-MI; O'Hara, Tokyo, Japan). Before experiments the chamber was cleaned with $1 \%$ acetic acid. The conditioning chamber was surrounded by a sound-attenuating chest with an observation window and was illuminated by a $13 \mathrm{~W}$ fluorescent lamp; masking noise of $65 \mathrm{~dB}$ was provided by a ventilation fan. Scrambled shock $(1 \mathrm{sec}, 0.5 \mathrm{~mA})$ was delivered by a shock generator/scrambler to the grid floor that was composed of 14 stainless steel rods $2 \mathrm{~mm}$ in diameter spaced $7 \mathrm{~mm}$ apart (center to center). Freezing was monitored continuously by an observer blind to mouse genotype and was recorded on a chart via a switch (see Fig. 3). Freezing was defined as the absence of any visible movement of the body and vibrissae except for movement necessitated by respiration (Fanselow, 1984). Behaviors of mice were recorded on videotapes. Freezing time was summated, and the percentage of freezing was calculated per minute. The data were analyzed by ANOVA.

Tone-dependent fear conditioning. Mice were placed in the conditioning chamber for $2 \mathrm{~min}$ and then presented with a loud tone of $\sim 75 \mathrm{~dB}$ and $800 \mathrm{~Hz}$ for $1 \mathrm{~min}$ through a speaker on the side wall of the conditioning chamber. At the end of the tone presentation the mice were given a footshock ( $1 \mathrm{sec}, 0.5 \mathrm{~mA})$. Freezing responses were monitored for $1 \mathrm{~min}$ more after footshock, and then the animals were returned to their home cages. On the next day the mice were placed in a novel chamber (reformed from a mouse home cage with clear polycarbonate boards, $12.5 \times 12.0 \times 11.0 \mathrm{~cm})$ with contexts different from those of the conditioning chamber to minimize the freezing caused by contextual fear conditioning; freezing was scored for $3 \mathrm{~min}$ before the tone presentation and subsequently for $3 \mathrm{~min}$ in the presence of the tone.

Contextual fear conditioning. Mice were placed in the conditioning chamber for various times (from 0 to $9 \mathrm{~min}$ ) and then given a footshock $(1 \mathrm{sec}, 0.5 \mathrm{~mA})$. Freezing responses were monitored for $1 \mathrm{~min}$ more after the footshock, and then the animals were returned to their home cages. On the next day the mice were placed in the conditioning chamber and freezing was scored for $6 \mathrm{~min}$.

\section{RESULTS}

\section{LTP induction in GluRe1 mutant mice}

We have shown that synaptic responses mediated by NMDA receptor channels and LTP in the hippocampal CA1 region are reduced in GluR $\epsilon 1$ mutant mice (Sakimura et al., 1995). Although the reduced LTP is likely to be attributable to a decrease in influx of $\mathrm{Ca}^{2+}$ through postsynaptic NMDA receptor channels, it has not yet been examined whether the reduced NMDA receptor channel activity primarily causes the impairment of LTP. It is also possible that the absence of the GluR $\epsilon 1$ subunit secondarily gives rise to any disturbance in the LTP-inducing intracellular processes after NMDA receptor channel activation. We examined this issue by manipulating the activity of NMDA receptor channels during high-frequency stimulation. If the reduction of LTP in the mutant mice is entirely attributable to the reduced number of existing NMDA receptor channels (or attributable to the increased threshold for LTP induction), stronger activation of the NMDA receptor channel should restore the reduced LTP.

We first examined the effects of increased stimulus strength during tetanic stimulation on LTP in the hippocampal CA1 region of the wild-type $(+/+)$ and GluR $\epsilon 1$ mutant $(-/-)$ mice, which would cause stronger depolarization of the postsynaptic cell, allowing a larger influx of $\mathrm{Ca}^{2+}$ through NMDA receptor channels. To compare the effect of the stimulus strength of tetanic stimulation precisely, we made two-pathway recordings in a single slice. Thus, two independent afferent inputs were stimulated alternately and a standard tetanus was delivered to one pathway, while a strong tetanus, which evoked twofold larger EPSPs in slope value than the baseline EPSPs, was given to the other pathway. In the mutant mice, tetanic stimulation with the standard stimulus strength gave rise to quite small magnitude LTP (111 $\pm 7 \%$ of control, $n=7$ ) (Fig. $1 A$, open circles), as reported previously (Sakimura et al., 1995), whereas a stronger tetanus with the same stimulation pattern restored the impaired LTP to the normal level $(130 \pm 5 \%$ of control; $p<0.01$, paired Student's $t$ test) (Fig. $1 A$, filled circles). The standard conditioning produced normal LTP in the wild-type mice $(135 \pm 6 \%$ of control, $n=4)$ (Fig. $1 B$,open circles), and increasing the stimulus strength during the tetanus had little effect on LTP $(132 \pm 10 \%$ of control) (Fig. $1 B$, filled circles). These results suggest that the stronger depolarization caused by the stronger tetanic stimulation, which would 
Figure 1. Stronger tetanic stimulation restores the impaired LTP in GluR $\epsilon 1$ mutant mice. $A, B$, Time courses of LTP in the mutant $(A)$ and wild-type $(B)$ mice. Two independent pathways were stimulated alternately. In one pathway a standard tetanus was applied at time 0 (open circles; $n=7$ in $A$ and $n=4$ in $B$ ). In the other pathway a stronger tetanus was delivered with some time lag ( filled circles). The pathway to which the stronger tetanic stimulation was given was selected at random for each experiment. Sample traces represent EPSPs recorded at the times indicated by the numbers in the graph. Stimulus artifacts are truncated. EPSP slopes are normalized by the averaged slope value of control EPSPs before tetanic stimulation.

A
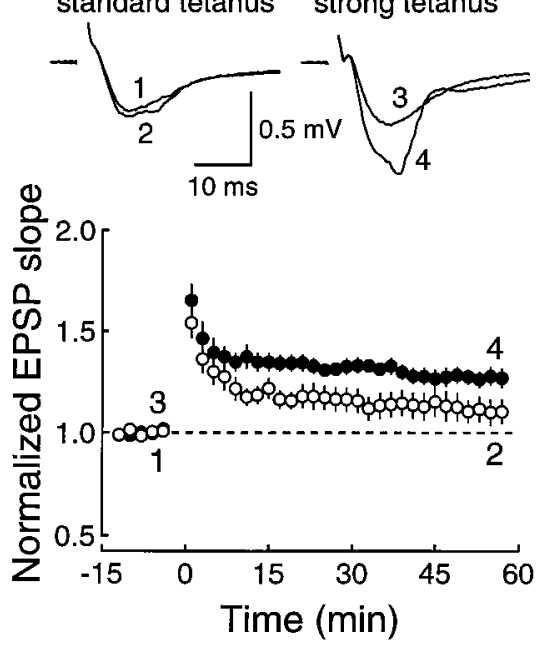

B

$+/+$ standard tetanus strong tetanus
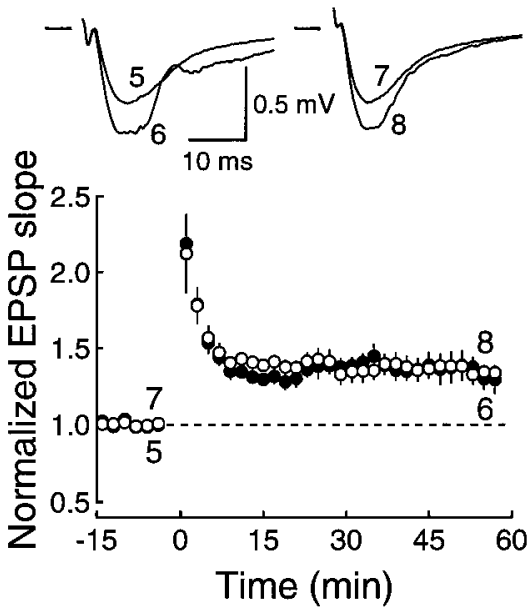

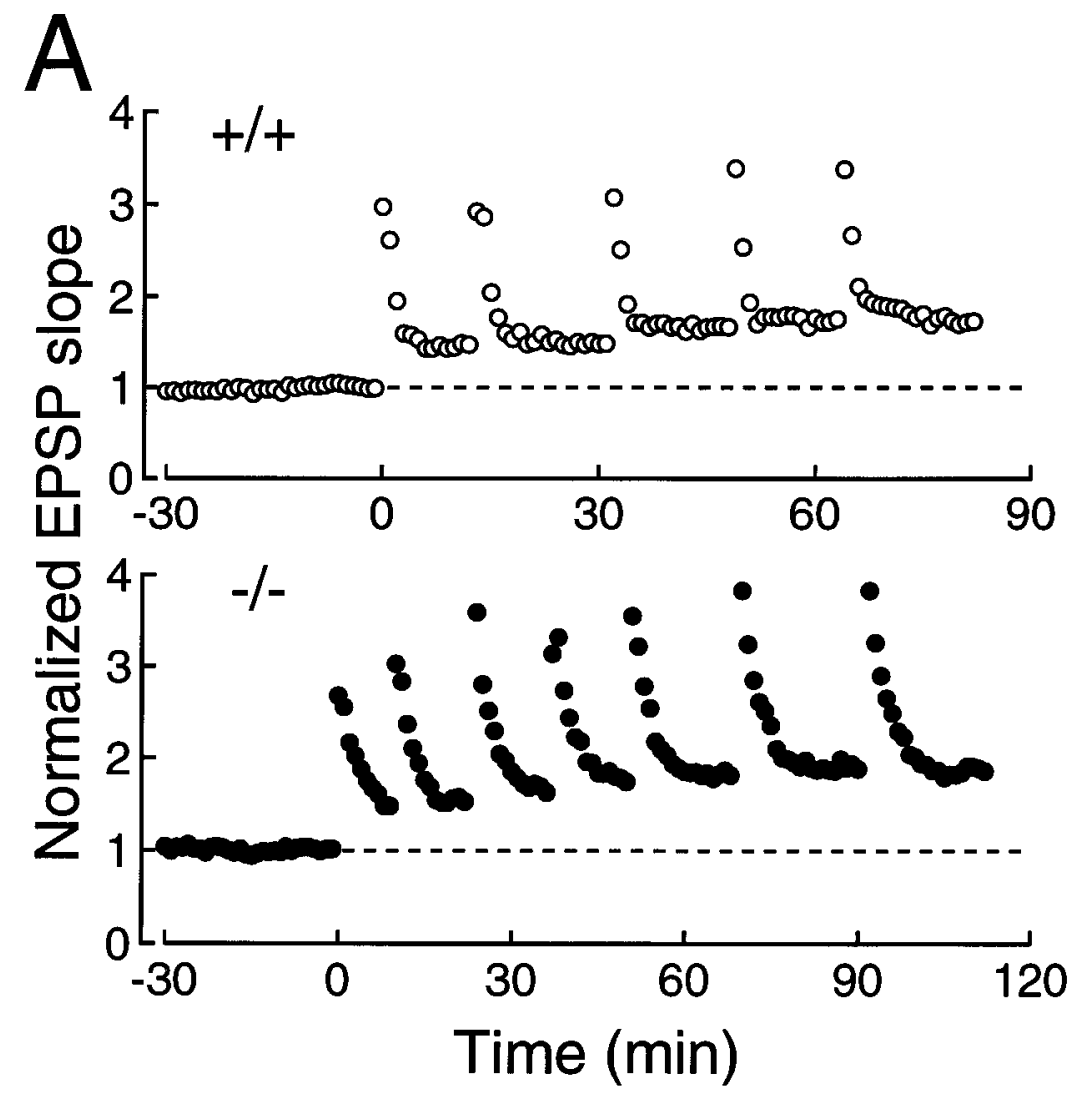

$\mathrm{B}$

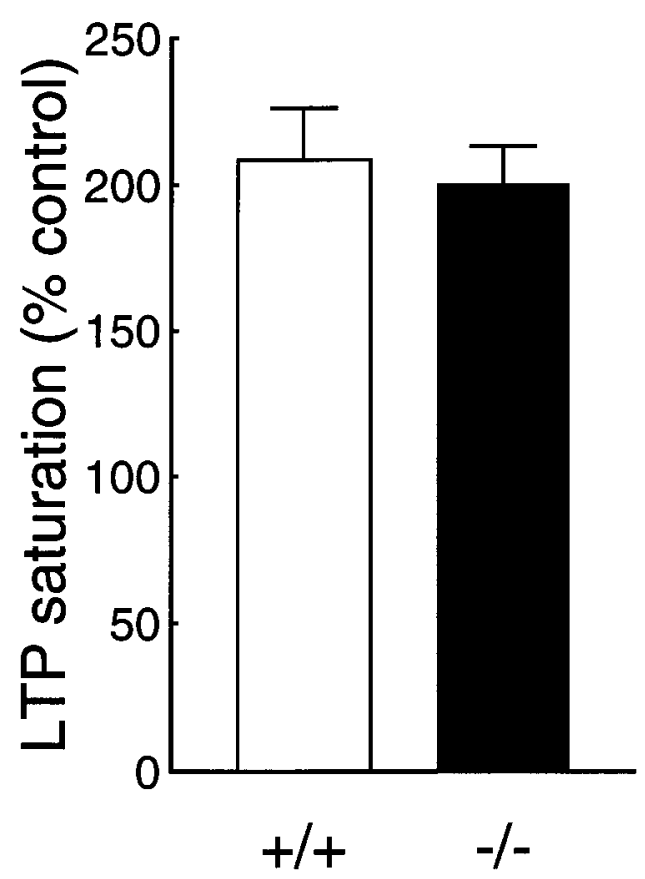

Figure 2. Saturation level of LTP. A, Examples of LTP saturation in the wild-type (open circles) and GluR $\epsilon 1$ mutant ( filled circles) mice. B, Summary of LTP saturation measurements.

activate NMDA receptor channels more efficiently, can rescue the reduced LTP and that the impairment of LTP is likely to be the result of an increased threshold for the LTP induction process in the GluR $\epsilon 1$ mutant mice.

If the impairment of LTP is attributable solely to the increased threshold for the LTP induction and is not attributable to the perturbation of LTP expression mechanisms, the saturation level of LTP in the mutant mice is expected to be the same as that in the wild-type mice. To saturate LTP, we repeatedly applied high-frequency stimulation until no more potentiation was observed (Fig. $2 A$ ). The saturation level of LTP was not significantly different ( $p=0.36$, unpaired $t$ test) between the wild-type (209 \pm $18 \%$ of control, $n=7)$ and mutant $(200 \pm 13 \%$ of control, $n=7)$ mice (Fig. $2 B$ ). These results further suggest that the impairment 

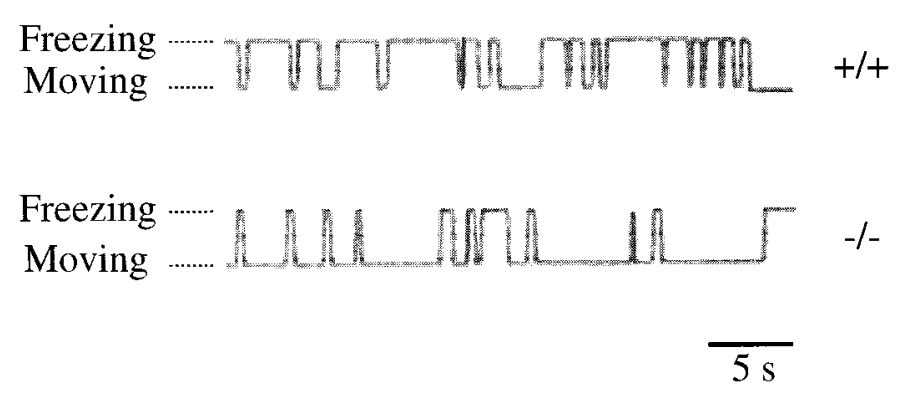

Figure 3. Recording of freezing responses. Samples of records from the wild-type and mutant mice are shown. Freezing is upward, and moving is downward.

of LTP induced by a single train of high-frequency stimulationmost likely is attributable to the increased threshold for the induction and that the LTP expression mechanisms are intact.

\section{GluRe1 mutant mice with a highly homogenous genetic background}

It is well established that the genetic background significantly affects the behaviors of mice (Crawley, 1996; Gerlai, 1996; Lathe, 1996). Among mouse strains, C57BL/6 performs various learning tasks well, such as the Morris water maze and contextual fear conditioning (Owen et al., 1997). Because we produced GluRe1 mutant mice by homologous recombination in TT2 ES cells derived from C57BL/6 × CBA F1 hybrid (Yagi et al., 1993) by using a targeting vector with genomic DNA from C57BL/6 mouse (Sakimura et al., 1995), we used a backcross strategy to examine the effect of the disruption of the GluR $\epsilon 1$ gene on learning behaviors under a pure $\mathrm{C} 57 \mathrm{BL} / 6$ genetic background. After 12 backcrosses to C57BL/6 strain, we obtained F13 GluRe1 mutant mouse with a calculated C57BL/6 genetic background of $99.99 \%$.

\section{Fear conditioning and genetic background}

We used fear conditioning tests to examine the learning ability of GluR $\epsilon 1$ mutant mice with a highly homogeneous genetic background. Fear conditioning is a rapidly acquired and persistent form of simple associative learning between an aversive footshock and a conditional stimulus such as a tone and an experimental chamber (Fanselow, 1984). The freezing response is characterized by an immobile, crouching posture and is the dominant defense reaction to the conditional fear in rodents (Fanselow, 1984).

For the assessment of the freezing response we judged the behaviors of the experimental mice to be freezing or not at every moment by using a switch recorder, as exemplified in Figure 3. By this switch-recording method, we obtained the entire profile of the freezing behavior and calculated the percentage of the total freezing time as an index of the extent of the freezing response. In the following analyses we used wild-type and GluR $\epsilon 1$ mutant mice from $\mathrm{P} 35$ to $\mathrm{P} 48$.

To assess the effect of the homogeneity of the genetic background on the contextual fear conditioning, we compared the wild-type littermates of F13 mice (calculated C57BL/6 genetic background, $99.99 \%$ ) with those of $\mathrm{F} 2$ mice (75\%), together with parental C57BL/6 and CBA mice (Fig. 4). Mice were placed in the conditioning chamber and were given one footshock at $3 \mathrm{~min}$ after placement. One minute after footshock the mice were returned to home cages. On the next day the animals were returned to the conditioning chamber, and their freezing behaviors were monitored for 6 min. C57BL/6 mice showed high levels

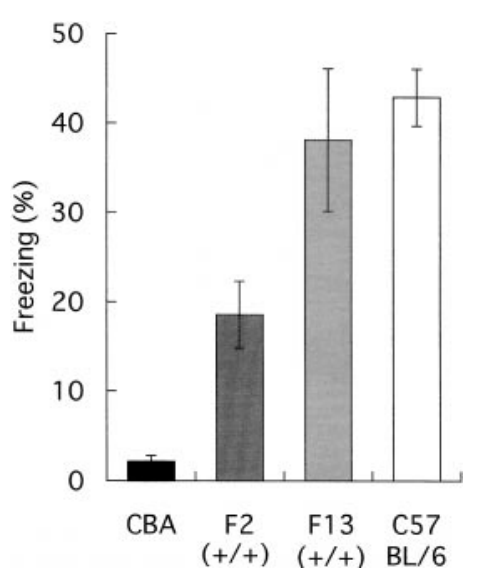

Figure 4. Effects of genetic backgrounds on freezing responses in contextual fear conditioning. Mice were given a footshock 3 min after placement in the conditioning chamber. The freezing responses were monitored for 6 min on the next day. The wild-type littermates of F2 and F13 GluR $\epsilon 1$ mice were compared for their ability of contextual learning with parental C57BL/6 and CBA mice.

of freezing time (43 $\pm 3 \%, n=21)$, as described previously (Paylor et al., 1994; Owen et al., 1997), whereas CBA mice exhibited a very low level of freezing responses $(2.2 \pm 0.6 \%, n=$ 12 ), and other defense reactions, such as tail ratting and a crouching position, were observed. Thus, there was a significant difference in contextual freezing responses between the two strains $\left(F_{(1,31)}=93.6 ; p<0.001\right)$. The extent of freezing of F13 mice $(38 \pm 8 \%, n=10)$ was as high as that of C57BL/6 mice $\left(F_{(1,29)}=\right.$ $0.48 ; p=0.49)$, whereas that of F2 mice $(19 \pm 4 \%, n=29)$ was significantly lower $\left(F_{(1,48)}=23 ; p<0.001\right)$. There was no significant difference between C57BL/6 and F13 mice. Thus, the backcrosses yielded the GluR $\epsilon 1$ mutant mice with a high ability to perform fear conditioning.

\section{Tone-dependent fear conditioning}

There are two paradigms in fear conditioning (Kim and Fanselow, 1992; Phillips and LeDoux, 1992). One form is the pairing of an aversive footshock with specific cues, such as a tone, which is insensitive to hippocampal lesions. The other is the pairing with nonspecific cues, such as the context of an experimental chamber, which is sensitive to hippocampal lesions. First, we tested the mutant mice in the tone-dependent fear conditioning task. Mice were placed in the conditioning chamber. After 2 min, a tone was presented for $1 \mathrm{~min}$ and a footshock was given at the end of the tone presentation. Figure $5 A$ shows the percentage of the freezing time averaged every minute during conditioning. Both the wild-type and mutant mice exhibited a slight freezing during tone presentation $(+/+, 2.4 \pm 0.6 \%, n=7 ;-/-, 2.0 \pm$ $1.0 \%, n=5)$ and after the footshock $(+/+, 7.5 \pm 2.6 \%, n=7$; $-/-, 6.7 \pm 3.1 \%, n=5)$. There were no differences in the extent of freezing between the two genotypes (during tone presentation, $F_{(1,10)}=0.15, p=0.71$; after footshock, $\left.F_{(1,10)}=0.051, p=0.83\right)$. On the next day the animals were placed in a chamber with novel contexts, and the tone was presented 3 min after placement (Fig. $5 B$ ). Until the tone was presented, the wild-type and mutant mice displayed only a weak freezing behavior in the novel chamber $(+/+, 4.9 \pm 1.5 \%, n=7 ;-/-, 4.2 \pm 0.5 \%, n=5)$. When the tone was presented, both the wild-type and mutant mice showed strong freezing responses $(+/+, 55 \pm 8 \%, n=7 ;-/-, 56 \pm 6 \%, n=5)$, and the extent of the freezing did not differ significantly between 
Figure 5. Freezing responses of the wild-type (open circles) and GluR $\epsilon 1$ mutant ( filled circles) mice in tone-dependent fear conditioning. $A$, Freezing responses on the conditioning day. Two minutes after placement in the conditioning chamber a tone was presented for $1 \mathrm{~min}$ (solid line), and mice were given a footshock (arrow) at the end of the tone presentation. $B$, Freezing responses on the next day. Three minutes after placement in a testing chamber with novel contexts, a tone was presented (solid line).

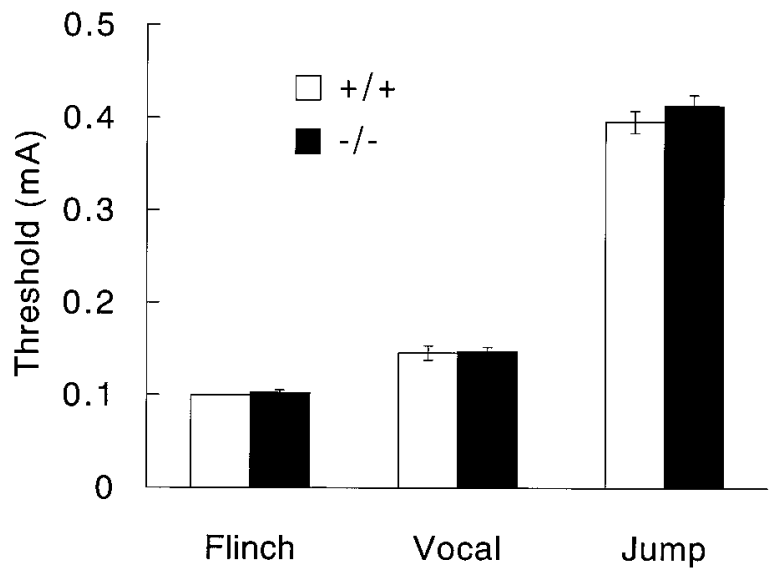

Figure 6. Current thresholds of the wild-type (open boxes) and GluR $\epsilon 1$ mutant ( filled boxes) mice for flinch, vocal, and jump reactions.

the two groups $\left(F_{(1,10)}=0.003 ; p=0.96\right)$. Thus, GluR $\epsilon 1$ mutant mice were apparently normal in the performance of the tonedependent fear response.

Because pain sensitivity would affect freezing responses, we measured current thresholds for three reactions of mice to nociceptive shock, namely, flinch, vocalization, and jump (Kim et al., 1991). Mice were given footshocks of increasing strength ranging from 0.1 to $0.5 \mathrm{~mA}$ in a stepwise manner by $0.05 \mathrm{~mA}$. Mice of both genotypes exhibited flinch responses at $0.1 \mathrm{~mA}(+/+, n=$ $12 ;-/-, n=19)$ except for one mutant mouse $(0.15 \mathrm{~mA})$. There were no significant differences between the wild-type and mutant mice in pain thresholds for vocal $(+/+, 0.15 \pm 0.01 \mathrm{~mA}, n=12$; $\left.-/-, 0.15 \pm 0.01 \mathrm{~mA}, n=19 ; F_{(1,29)}=0.034 ; p=0.85\right)$ and jump reactions $(+/+, 0.40 \pm 0.01 \mathrm{~mA}, n=12 ;-/-, 0.41 \pm 0.01 \mathrm{~mA}$, $n=19 ; F_{(1,29)}=1.04 ; p=0.32$ ) (Fig. 6).

\section{Contextual fear conditioning}

We then examined the contextual fear conditioning that is sensitive to hippocampal lesions (Kim and Fanselow, 1992; Phillips and LeDoux, 1992). Mice were placed in the conditioning chamber and were given one footshock 3 min after placement (Fig. $7 E$ ). Mice were removed $1 \mathrm{~min}$ after footshock and returned to home cages. On the next day the animals were returned to the chamber, and their freezing behaviors were monitored for $6 \mathrm{~min}$ (Fig. $7 F$ ).

On the conditioning day the mice placed in the conditioning chamber showed little or no freezing responses (Fig. 7E). During the $1 \mathrm{~min}$ immediately after the footshock both the wild-type and
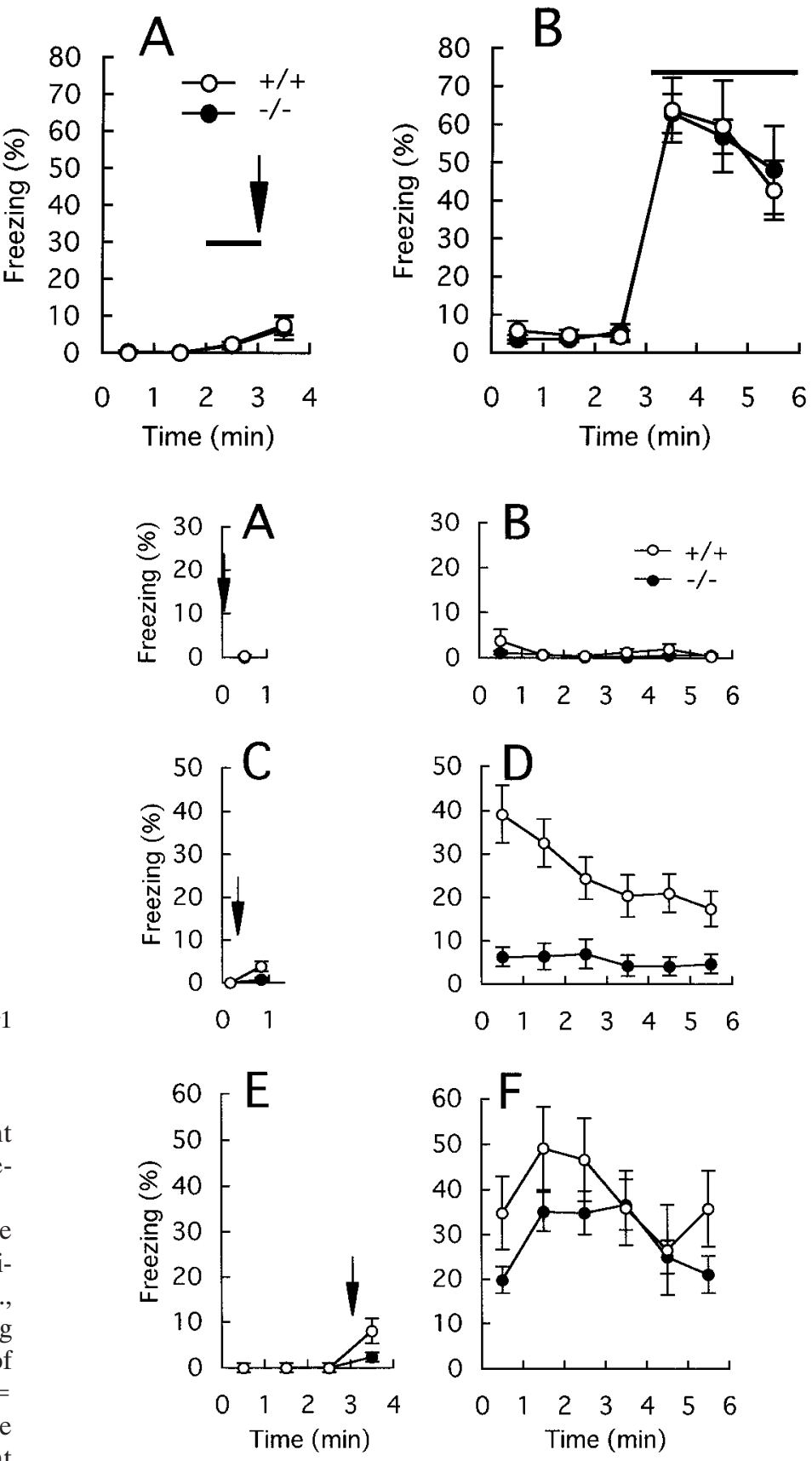

Figure 7. Freezing responses of the wild-type (open circles) and GluR $\epsilon 1$ mutant ( filled circles) mice on the conditioning day $(A, C, E)$ and on the next day $(B, D, F)$ in contextual fear conditioning. A footshock (arrows) was given immediately $(A), 20 \mathrm{sec}(C)$, or $3 \mathrm{~min}(E)$ after placement of the mice in the conditioning chamber. Freezing responses were monitored for 1 min after shock on the conditioning day and for 6 min on the next day.

mutant mice exhibited slight freezing responses $(+/+, 8.1 \pm$ $2.7 \%, n=10 ;-/-, 2.4 \pm 1.0 \%, n=24)$. However, there was a significant difference in the extent of the freezing immediately after shock (FIAS) between the wild-type and mutant mice $\left(F_{(1,32)}=6.4 ; p=0.016\right)$. When returned to the conditioning chamber on the next day (Fig. $7 F$ ), both the wild-type and mutant mice showed strong freezing responses during the 6 min period $(+/+, 38 \pm 8 \%, n=10 ;-/-, 29 \pm 3 \%, n=24)$, and there was no significant difference in the extent of freezing between these 
animals $\left(F_{(1,32)}=1.75 ; p=0.20\right)$. Thus, the GluR $\epsilon 1$ mutation affected FIAS on the conditioning day.

These observations tempted us to examine further the contextual fear conditioning under weaker conditioning stimuli by decreasing the time interval between the placement in the conditioning chamber (the exposure time to the chamber) and footshock. When a footshock was given immediately after placement in the chamber, both the wild-type and mutant mice exhibited little or no freezing responses on the conditioning day (Fig. $7 A$ ) and on the next day (Fig. $7 B$ ). Thus, a certain exposure time to the chamber before footshock is essential for both FIAS and freezing responses on the next day, indicating that both types of fear responses are associative in nature, as described for rats (Fanselow, 1986).

When a footshock was given at $20 \mathrm{sec}$ after placement, the wild-type mice showed a weak but significant FIAS $(3.9 \pm 1.2 \%$, $n=22$ ) (Fig. 7C). On the other hand, the mutant mice exhibited less FIAS $(0.8 \pm 0.4 \%, n=26)$ than the wild-type mice $\left(F_{(1,46)}=\right.$ $7.4 ; p<0.01)$. On the next day of conditioning the wild-type mice exhibited strong freezing responses $(26 \pm 4 \%, n=22)$, indicating that the chamber exposure time of $20 \mathrm{sec}$ was sufficient for the wild-type mice to be fear-conditioned (Fig. 7D). In contrast, the mutant mice showed only a weak response $(5.5 \pm 2.4 \%, n=26)$, and there was a significant difference in the contextual fear conditioning between the wild-type and mutant mice $\left(F_{(1,46)}=\right.$ $19.1 ; p<0.001)$. These results suggest that the contextual learning of the GluR $\epsilon 1$ mutant mice is impaired under a weak conditional stimulus (short chamber exposure time).

Then we further examined the extent of the contextual fear conditioning by giving a footshock at various time intervals after placement in the conditioning chamber (Fig. 8). On the conditioning day both the wild-type and mutant mice exhibited slight freezing responses during the 1 min after the footshock, and the extent of FIAS gradually increased when the time interval between the placement in the conditioning chamber and the footshock became longer (Fig. $8 A$ ). However, GluR $\epsilon 1$ mutant mice showed significantly less FIAS than the wild-type mice at time intervals of $20 \mathrm{sec}\left(F_{(1,46)}=7.4 ; p<0.01\right), 30 \mathrm{sec}\left(F_{(1,54)}=5.0\right.$; $p=0.03), 1 \min \left(F_{(1,39)}=9.3 ; p<0.01\right), 3 \min \left(F_{(1,32)}=6.4 ; p=\right.$ $0.02)$, and $9 \min \left(F_{(1,22)}=23 ; p<0.001\right)$. Because FIAS is associative in nature and the mutant mice performed normally the tone-dependent freezing response (see above), these results suggest that associative learning immediately after the contextual conditioning is impaired in GluR $\epsilon 1$ mutant mice.

The contextual freezing responses on the next day of the conditioning also increased when the time interval between the placement in the conditioning chamber and the footshock became longer (Fig. 8B). However, the chamber exposure time (conditioning stimulus)-freezing response curve for the mutant mice shifted rightward as compared with that of the wild-type mice, and there was a significant difference in the contextual freezing responses between the wild-type and mutant mice at time intervals of $20 \sec \left(F_{(1,46)}=19 ; p<0.001\right), 30 \sec \left(F_{(1,54)}=9.1 ; p<\right.$ $0.01)$, and $1 \mathrm{~min}\left(F_{(1,39)}=9.3 ; p<0.001\right)$. The saturation level of the freezing response was comparable between the wild-type and mutant mice (at $3 \mathrm{~min}, F_{(1,32)}=1.75, p=0.20$; at $9 \mathrm{~min}, F_{(1,22)}=$ $0.47, p=0.50)$. These results suggest that the threshold for the contextual learning increases in GluR $\epsilon 1$ mutant mice. Furthermore, the difference in the extent of FIAS on the conditioning day does not necessarily correlate to the contextual fear memory on the next day.
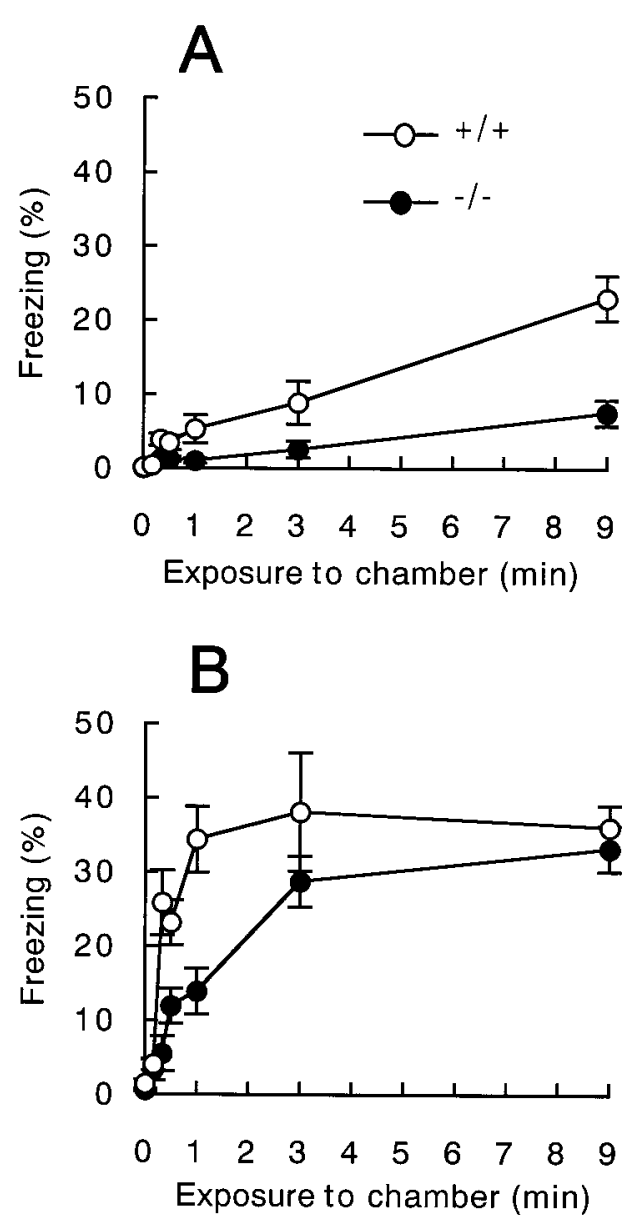

Figure 8. Effects of chamber exposure time on the freezing responses of the wild-type (open circles) and GluR $\epsilon 1$ mutant (filled circles) mice in contextual fear conditioning. A footshock was given at $0,10,20$, and $30 \mathrm{sec}$ and 1,3 , or $9 \mathrm{~min}$ after placement of the mice in the conditioning chamber. The freezing responses during the 1 min immediately after shock on the conditioning day $(A)$ and those during 6 min after placement in the conditioning chamber on the next day $(B)$ were plotted as a function of the time interval between the placement in the chamber and footshock on the conditioning day.

\section{Freezing immediately after shock}

Because GluR $\epsilon 1$ mutant mice showed an impairment of FIAS, we tested the effect of additional shocks (Fig. 9). Mice were placed in the conditioning chamber for $3 \mathrm{~min}$, and then three footshocks were given at $1 \mathrm{~min}$ intervals. Mice were removed from the chamber $1 \mathrm{~min}$ after the last footshock and returned to home cages. The extent of the freezing responses increased after every footshock in both the wild-type and mutant mice (Fig. 9A). Even after three footshocks, however, the extent of the freezing response of the GluR $\epsilon 1$ subunit mutant mice during 1 min $(23 \pm$ $11 \%, n=5)$ was significantly less than that of the wild-type mice $(64 \pm 6 \%, n=6)\left(F_{(1,9)}=14.4 ; p=0.004\right)$. In contrast, there was no significant difference in the extent of contextual freezing responses on the next day between the wild-type and mutant mice $(+/+, 73 \pm 5 \%, n=6 ;-/-, 57 \pm 5 \%, n=5)\left(F_{(1,9)}=6.9 ; p=\right.$ 0.28) (Fig. 9B).

We then asked how long the difference in FIAS between the wild-type and mutant mice was retained. Mice were placed in the conditioning chamber and given a footshock 3 min after placement in the conditioning chamber. Freezing responses of a group 

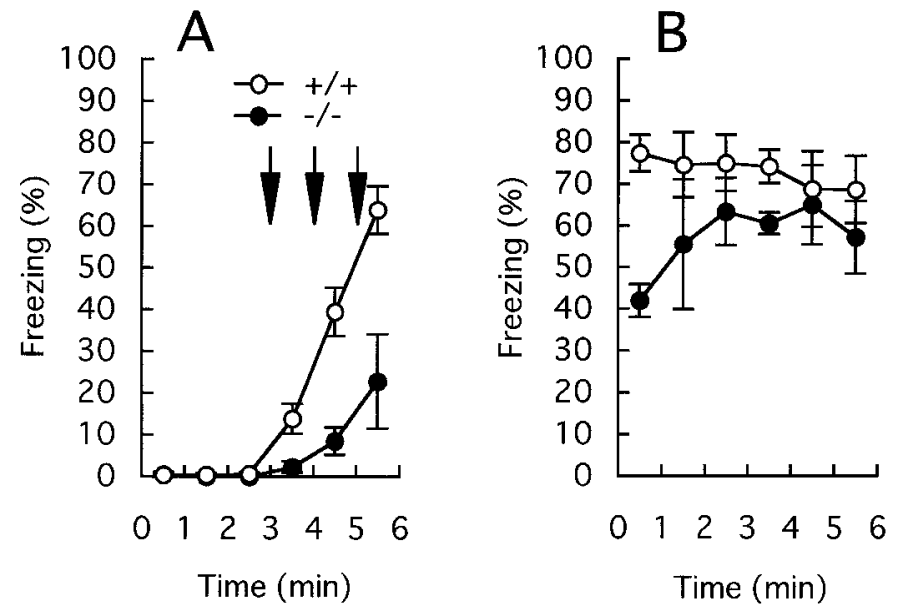

Figure 9. Freezing responses of the wild-type (open circles) and GluR $\epsilon 1$ mutant ( filled circles) mice on the conditioning day $(A)$ and on the next day $(B)$ when footshocks (arrows) were given at 3, 4, and 5 min after placement in the conditioning chamber. Freezing responses were monitored for $1 \mathrm{~min}$ after the last shock on the conditioning day and for $6 \mathrm{~min}$ on the next day.

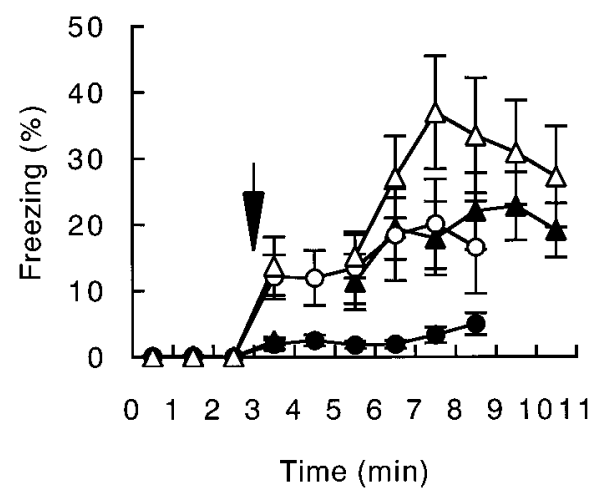

Figure 10. Freezing responses of the wild-type (open symbols) and GluR $\epsilon 1$ mutant ( filled symbols) mice immediately and 2 min after footshock. Mice were given a footshock (arrow) 3 min after placement in the conditioning chamber. Freezing responses of one group of mice (circles) were monitored for $8 \mathrm{~min}$ after the footshock, and those during the initial 6 min are shown for comparison; the extent of freezing during the last 2 min was essentially the same as that during the initial $6 \mathrm{~min}$. Another group of mice (triangles) was removed from the conditioning chamber 1 min after the footshock, returned to the conditioning chamber at $2 \mathrm{~min}$ after the footshock, and monitored for freezing responses for $6 \mathrm{~min}$.

of mice were monitored for 6 min after the footshock (Fig. 10, circles). There was a significant difference in FIAS monitored for 6 min between the wild-type (open circles, $18 \pm 5 \%, n=12$ ) and mutant ( filled circles, $3.7 \pm 0.6 \%, n=13)$ mice $\left(F_{(1,23)}=6.7 ; p=\right.$ $0.017)$. Another group of mice was removed from the conditioning chamber 1 min after the footshock, placed in home cages, and returned to the conditioning chamber at $20 \mathrm{~min}$ after the footshock; freezing responses were monitored for $6 \mathrm{~min}$. The freezing responses of the mutant mice 20 min after conditioning ( $21 \pm 4 \%$, $n=9)$ were significantly higher than the FIAS of the mutant mice $\left(F_{(1,20)}=35 ; p<0.001\right)$ and became comparable with those of the wild-type mice $(24 \pm 7 \%, n=8)\left(F_{(1,15)}=0.14 ; p=0.71\right)$. Even when mice were returned to the conditioning chamber 2 min after conditioning (Fig. 10, triangles), the freezing responses of the mutant mice during the 6 min period (filled triangles, $19 \pm 4 \%$, $n=13$ ) were significantly higher than the FIAS of the mutant mice $\left(F_{(1,24)}=15 ; p<0.001\right)$ and were comparable with those of the wild-type mice (open triangles, $29 \pm 6 \%, n=11)\left(F_{(1,22)}=2.0\right.$; $p=0.17)$.

\section{DISCUSSION}

\section{Increased threshold for LTP induction}

It generally is agreed that postsynaptic NMDA receptor channels (Collingridge et al., 1983) and $\mathrm{Ca}^{2+}$ influx through the channels (Lynch et al., 1983; Malenka et al., 1988) play crucial roles in the induction of LTP in the CA1 region of the hippocampus. The degree of NMDA receptor channel activation determines the threshold for LTP induction (Malenka, 1991), and the amount of $\mathrm{Ca}^{2+}$ influx through the channel regulates the magnitude and direction of changes in synaptic efficacy (Perkel et al., 1993; Cummings et al., 1996). We have shown that the disruption of the GluR $\epsilon 1$ subunit causes a partial reduction of LTP in the hippocampal CA1 region (Sakimura et al., 1995). In these mice the size of synaptic responses mediated by NMDA receptor channels is approximately one-half that of the wild-type mice, suggesting that the GluR $\epsilon 1$ subunit contributes, together with the GluR $\zeta 1$ subunit, to one-half of the NMDA synaptic transmission and that the remaining NMDA synaptic responses are mediated exclu-

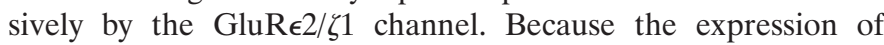
GluRe2 subunit proteins is unchanged in GluRe1 mutant mice (Sakimura et al., 1995), the reduction of LTP magnitudes in the mutant mice can be explained most easily by the decrease in the number of active NMDA receptor channels, which would increase the threshold for LTP.

In the present study we have examined these issues more directly by manipulating the activation of NMDA receptor channels in the mutant mice. When NMDA receptor channels are activated more strongly (by stronger tetanic stimulation) or repeatedly (by multiple trains of tetanic stimulation), resulting LTP seems to be normal in the mutant mice. These results strongly suggest that the impairment of LTP observed in the mutant mice is caused by the reduction of $\mathrm{Ca}^{2+}$ influx attributable to the absence of the GluR $\epsilon 1$ subunit and that LTP expression mechanisms after $\mathrm{Ca}^{2+}$ influx are not affected by the ablation of the GluR $\epsilon 1$ subunit. Furthermore, they also indicate that, although the GluR $\epsilon 1$ subunit is involved in the LTP induction, the GluR $\epsilon 2$ subunit can substitute for the GluR $\epsilon 1$ subunit in the process of synaptic plasticity in the hippocampus.

We did not observe any enhancement of LTP by tetanic stimulation with the stronger stimulus strength in the wild-type slices. It is possible that $\mathrm{Ca}^{2+}$ influx during the standard tetanus may already reach saturation level for LTP induction. Alternatively, the larger depolarization by the stronger tetanus may reduce the driving force for $\mathrm{Ca}^{2+}$ influx through NMDA receptor channels, resulting in no apparent changes in $\mathrm{Ca}^{2+}$ influx. On the other hand, in the mutant slices, depolarization during the standard tetanus may not be sufficient to remove a voltage-dependent $\mathrm{Mg}^{2+}$ block of NMDA receptor channels completely, and stronger tetanus may depolarize the cells to the level more favorable for LTP induction.

\section{Increased threshold for contextual learning}

Because various inbred mouse strains exhibit wide variations in their performance of learning behaviors (Crawley, 1996; Gerlai, 1996; Lathe, 1996; Owen et al., 1997), it is important to examine the effect of eliminating any specific gene on learning behaviors under a homogeneous genetic background. We produced a GluR $\epsilon 1$ mutant mouse line with a highly homogeneous C57BL/6 
genetic background (calculated to be $99.99 \%$ pure) by successive backcrosses. The performance of contextual fear conditioning of the wild-type littermates of the established F13 line was as high as that of C57BL/6 mice, whereas the wild-type F2 littermates with a genetic background of $75 \% \mathrm{C} 57 \mathrm{BL} / 6$ exhibited a lower level of freezing responses. Thus, the mutant mice with a highly homogeneous genetic background will provide a valuable tool to investigate the physiological role of the GluR $\epsilon 1$ subunit of the NMDA receptor channel. Furthermore, monitoring the freezing responses of mice at every moment with a switch recorder made it possible to obtain exact and entire profiles of the freezing responses.

GluR $\epsilon 1$ mutant mice performed two types of fear conditioning tests under single conditioning shock, although they showed impairment in the performance of the Morris water maze task (Sakimura et al., 1995). Similarly, a transgenic mouse with a mutant $\mathrm{Ca}^{2+} /$ calmodulin kinase II showed impairment in hippocampal LTP and spatial learning, but not in contextual learning (Bach et al., 1995). However, deficiency in contextual learning of GluR $\epsilon 1$ mutant mice became evident when the conditioned stimulus was weakened by shortening the time interval between the placement in the conditioning chamber and the footshock. Systematic analyses of contextual learning under various chamber exposure times revealed that the conditioning stimulus-freezing response curve shifted rightward in the mutant mice, whereas the saturation level of the freezing response was comparable with that of the wild-type mice. These results suggest that the deprivation of the GluR $\epsilon 1$ subunit increases the threshold for contextual learning. Thus, the present investigation provides evidence that the GluR $\epsilon 1$ subunit of the NMDA receptor channel is an important determinant of thresholds for both LTP and contextual learning. These findings suggest that the increased threshold for LTP induction results in a need for longer context exposure before the conditioning for robust learning can occur, implying a strong correlation between synaptic plasticity and contextual learning.

Recently, Sprengel et al. (1998) argued that the mutant mice expressing the GluR $\epsilon 1$ subunit lacking most of the large intracellular C-terminal region phenotypically resembled the GluR $\epsilon 1$ null mutant mice and that the $\mathrm{C}$-terminal domain was important for signal transduction. However, the impairment of hippocampal LTP and contextual fear conditioning seems to be more severe in the C-terminal-truncated GluR $\epsilon 1$ mutant mice than in the null mutant mice. The truncated GluR $\epsilon 1$ subunit may exert some abnormal dominant-negative effects. In fact, these mutant mice exhibit deficits in motor coordination, but such defects are not found in the null mutant mice (Kadotani et al., 1996).

\section{Impairment of freezing immediately after shock}

We found that GluR $\epsilon 1$ ablation strongly reduced FIAS on the conditioning day in the fear conditioning test. Because mice showed little freezing when the shock was given immediately after placement in the chamber and the extent of FIAS increased as the chamber exposure time became longer, this freezing response was associative in nature, as described in rats (Fanselow, 1986). Assuming that FIAS is associatively based (Kim et al., 1991), these results suggest that the GluR $\epsilon 1$ subunit of the NMDA receptor channel is critical for an associative memory immediately after conditioning.

When the interval between the placement in the conditioning chamber and footshock was lengthened, the deficit of contextual freezing on the next day was restored, but FIAS remained impaired in GluR $\epsilon 1$ mutant mice. Thus, FIAS does not relate directly to the contextual fear memory after $24 \mathrm{hr}$ of conditioning. These results suggest that there are two forms of contextual learning in mice, one immediately after conditioning and the other $1 \mathrm{~d}$ after conditioning. The former depends strongly on the GluR $\epsilon 1$ subunit of the NMDA receptor channel, whereas the latter requires the GluR $\epsilon 1$ subunit when the conditioning stimulus is weak. The differential effects of the GluR $\epsilon 1$ subunit on the two forms of fear conditioning suggest that different neural systems may underlie the two forms of memories. Intracerebroventricular inf usion of APV in rats produced selective deficits on the acquisition of contextual fear conditioning expressed $24 \mathrm{hr}$ after training but immediate postshock freezing was not affected (Kim et al., 1991, 1992), whereas intra-amygdaloid APV infusion impaired both (Maren et al., 1996). Thus, different brain regions may be responsible for the two forms of contextual learning. It is well established that the nuclei of the amygdala are essential for fear conditioning (Miserendino et al., 1990; LeDoux, 1995; Maren and Fanselow, 1996). In addition, the contextual fear conditioning is also sensitive to hippocampal lesions (Kim and Fanselow, 1992; Phillips and LeDoux, 1992), whereas post-training lesions of the dorsal hippocampus attenuated contextual freezing but had no effect on fear-potentiated startle (McNish et al., 1997). Among four GluR $\epsilon$ subunits of the NMDA receptor channel, the GluR $\epsilon 1$ and GluR $\epsilon 2$ subunits are expressed strongly in the amygdala and the hippocampus of the adult brain (Watanabe et al., 1992, 1993, 1998). Fine differences in functional properties (Seeburg, 1993; Mori and Mishina, 1995), localization, or contribution to synapses (Ito et al., 1997) between the two subunits may underlie the differential contribution of the GluR $\epsilon 1$ subunit to the two forms of contextual memories.

It is believed that the two forms of contextual fear memories are temporally distinct processes in rats: short-term conditional fear and long-term conditional fear (Kim et al., 1991, 1992). When GluR $\epsilon 1$ mutant mice were returned to the conditioning chamber 2 min after conditioning under sufficient chamber exposure time (3 min, Fig. 10), the freezing response of the mutant mice became significantly higher than FIAS to be comparable with that of the wild-type mice. Because the periods of measurement were greatly overlapped between two groups of mutant mice, the procedure of removal and placement again into the conditioning chamber, rather than the time after shock, appears to be responsible for the difference in the freezing responses of the GluR $\epsilon 1$ mutant mice measured immediately after shock and those 2 min after shock. Thus, the two forms of contextual fear memories we observed in mice may be procedurally, rather than temporally, distinct.

\section{REFERENCES}

Bach ME, Hawkins RD, Osman M, Kandel ER, Mayford M (1995) Impairment of spatial but not contextual memory in CaMKII mutant mice with a selective loss of hippocampal LTP in the range of $\theta$ frequency. Cell 81:905-915.

Bannerman DM, Good MA, Butcher SP, Ramsay M, Morris RG (1995) Distinct components of spatial learning revealed by prior training and NMDA receptor blockade. Nature 378:182-186.

Bliss TV, Collingridge GL (1993) A synaptic model of memory: longterm potentiation in the hippocampus. Nature 361:31-39.

Cline HT, Debski EA, Constantine-Paton M (1987) $N$-methyl-Daspartate receptor antagonist desegregates eye-specific stripes. Proc Natl Acad Sci USA 84:4342-4345.

Collingridge GL, Kehl SJ, McLennan H (1983) Excitatory amino acids in synaptic transmission in the Schaffer collateral-commissural pathway of the rat hippocampus. J Physiol (Lond) 334:33-46.

Crawley JN (1996) Unusual behavioral phenotypes of inbred mouse strains. Trends Neurosci 19:181-182.

Cummings JA, Mulkey RM, Nicoll RA, Malenka RC (1996) $\mathrm{Ca}^{2+}$ signaling requirements for long-term depression in the hippocampus. Neuron 16:825-833. 
Ebralidze AK, Rossi DJ, Tonegawa S, Slater NT (1996) Modification of NMDA receptor channels and synaptic transmission by targeted disruption of the NR2C gene. J Neurosci 16:5014-5025.

Fanselow MS (1980) Conditioned and unconditional components of post-shock freezing. Pavlov J Biol Sci 15:177-182.

Fanselow MS (1984) What is conditioned fear? Trends Neurosci $7: 460-462$.

Fanselow MS (1986) Associative vs topographical accounts of the immediate shock-freezing deficit in rats: implications for the response selection rules governing species-specific defensive reactions. Learn Motiv 17:16-39.

Forrest D, Yuzaki M, Soares HD, Ng L, Luk DC, Sheng M, Stewart CL, Morgan JI, Connor JA, Curran T (1994) Targeted disruption of NMDA receptor 1 gene abolishes NMDA response and results in neonatal death. Neuron 13:325-338.

Gerlai R (1996) Gene-targeting studies of mammalian behavior: is it the mutation or the background genotype? Trends Neurosci 19:177-181.

Hollmann M, Boulter J, Maron C, Beasley L, Sullivan J, Pecht G, Heinemann S (1993) Zinc potentiates agonist-induced currents at certain splice variants of the NMDA receptor. Neuron 10:943-954.

Ikeda K, Nagasawa M, Mori H, Araki K, Sakimura K, Watanabe M, Inoue Y, Mishina M (1992) Cloning and expression of the $\epsilon 4$ subunit of the NMDA receptor channel. FEBS Lett 313:34-38.

Ikeda K, Araki K, Takayama C, Inoue Y, Yagi T, Aizawa S, Mishina M (1995) Reduced spontaneous activity of mice defective in the $\epsilon 4$ subunit of the NMDA receptor channel. Mol Brain Res 33:61-71.

Ito I, Futai K, Katagiri H, Watanabe M, Sakimura K, Mishina M, Sugiyama H (1997) Synapse-selective impairment of NMDA receptor functions in mice lacking NMDA receptor $\epsilon 1$ or $\epsilon 2$ subunit. J Physiol (Lond) 500:401-408.

Kadotani H, Hirano T, Masugi M, Nakamura K, Nakao K, Katsuki M, Nakanishi S (1996) Motor discoordination results from combined gene disruption of the NMDA receptor NR2A and NR2C subunits, but not from single disruption of the NR2A or NR2C subunit. J Neurosci 16:7859-7867.

Kim JJ, Fanselow MS (1992) Modality-specific retrograde amnesia of fear. Science 256:675-677.

Kim JJ, DeCola P, Landeira-Fernandez J, Fanselow MS (1991) $N$-methyl-D-aspartate receptor antagonist APV blocks acquisition but not expression of fear conditioning. Behav Neurosci 105:126-133.

Kim JJ, Fanselow MS, DeCola JP, Landeira-Fernandez J (1992) Selective impairment of long-term but not short-term conditional fear by the $N$-methyl-D-aspartate antagonist APV. Behav Neurosci 106:591-596.

Kleinschmidt A, Bear MF, Singer W (1987) Blockade of "NMDA" receptors disrupts experience-dependent plasticity of kitten striate cortex. Science 238:355-358.

Kutsuwada T, Kashiwabuchi N, Mori H, Sakimura K, Kushiya E, Araki K, Meguro H, Masaki H, Kumanishi T, Arakawa M, Mishina M (1992) Molecular diversity of the NMDA receptor channel. Nature 358:36-41.

Kutsuwada T, Sakimura K, Manabe T, Takayama C, Katakura N, Kushiya E, Natsume R, Watanabe M, Inoue Y, Yagi T, Aizawa S, Arakawa M, Takahashi T, Nakamura Y, Mori H, Mishina M (1996) Impairment of suckling response, trigeminal neuronal pattern formation, and hippocampal LTD in NMDA receptor $\epsilon 2$ subunit mutant mice. Neuron 16:333-344.

Lathe R (1996) Mice, gene targeting, and behavior: more than just genetic background. Trends Neurosci 19:183-186.

LeDoux JE (1995) Emotion: clues from the brain. Annu Rev Psychol 46:209-235.

Li Y, Erzurumlu RS, Chen C, Jhaveri S, Tonegawa S (1994) Whiskerrelated neuronal patterns fail to develop in the trigeminal brainstem nuclei of NMDAR1 knock-out mice. Cell 76:427-437.

Lynch G, Larson J, Kelso S, Barrionuevo G, Schottler F (1983) Intracellular injections of EGTA block induction of hippocampal long-term potentiation. Nature 305:719-721.

Malenka RC (1991) Postsynaptic factors control the duration of synaptic enhancement in area CA1 of the hippocampus. Neuron 6:53-60.

Malenka RC, Nicoll RA (1993) NMDA receptor-dependent synaptic plasticity: multiple forms and mechanisms. Trends Neurosci 16:521-527.

Malenka RC, Kauer JA, Zucker RS, Nicoll RA (1988) Postsynaptic calcium is sufficient for potentiation of hippocampal synaptic transmission. Science 242:81-84.

Maren S, Fanselow MS (1996) The amygdala and fear conditioning: has the nut been cracked? Neuron 16:237-240.

Maren S, Aharonov G, Stote DL, Fanselow MS (1996) N-methyl-D- aspartate receptors in the basolateral amygdala are required for both acquisition and expression of conditional fear in rats. Behav Neurosci 110:1365-1374.

McNish KA, Gewirtz JC, Davis M (1997) Evidence of contextual fear after lesions of the hippocampus: a disruption of freezing but not fear-potentiated startle. J Neurosci 17:9353-9360.

Meguro H, Mori H, Araki K, Kushiya E, Kutsuwada T, Yamazaki M, Kumanishi T, Arakawa M, Sakimura K, Mishina M (1992) Functional characterization of a heteromeric NMDA receptor channel expressed from cloned cDNAs. Nature 357:70-74.

Miserendino MJ, Sananes CB, Melia KR, Davis M (1990) Blocking of acquisition but not expression of conditioned fear-potentiated startle by NMDA antagonists in the amygdala. Nature 345:716-718.

Monyer H, Sprengel R, Schoepfer R, Herb A, Higuchi M, Lomeli H, Burnashev N, Sakmann B, Seeburg PH (1992) Heteromeric NMDA receptors: molecular and functional distinction of subtypes. Science 256:1217-1221.

Mori H, Mishina M (1995) Structure and function of the NMDA receptor channel. Neuropharmacology 34:1219-1237.

Moriyoshi K, Masu M, Ishii T, Shigemoto R, Mizuno N, Nakanishi S (1991) Molecular cloning and characterization of the rat NMDA receptor. Nature 354:31-37.

Morris RG, Anderson E, Lynch GS, Baudry M (1986) Selective impairment of learning and blockade of long-term potentiation by an $N$-methyl-D-aspartate receptor antagonist, AP5. Nature 319:774-776.

Nagasawa M, Sakimura K, Mori KJ, Bedell MA, Copeland NG, Jenkins NA, Mishina M (1996) Gene structure and chromosomal localization of the mouse NMDA receptor channel subunits. Mol Brain Res 36:1-11.

Owen EH, Logue SF, Rasmussen DL, Wehner JM (1997) Assessment of learning by the Morris water task and fear conditioning in inbred mouse strains and F1 hybrids: implications of genetic background for single gene mutations and quantitative trait loci analyses. Neuroscience 80:1087-1099.

Paylor R, Tracy R, Wehner J, Rudy JW (1994) DBA/2 and C57BL/6 mice differ in contextual fear but not auditory fear conditioning. Behav Neurosci 108:810-817.

Perkel DJ, Petrozzino JJ, Nicoll RA, Connor JA (1993) The role of $\mathrm{Ca}^{2+}$ entry via synaptically activated NMDA receptors in the induction of long-term potentiation. Neuron 11:817-823.

Phillips RG, LeDoux JE (1992) Differential contribution of amygdala and hippocampus to cued and contextual fear conditioning. Behav Neurosci 106:274-285.

Sakimura K, Kutsuwada T, Ito I, Manabe T, Takayama C, Kushiya E, Yagi T, Aizawa S, Inoue Y, Sugiyama H, Mishina M (1995) Reduced hippocampal LTP and spatial learning in mice lacking NMDA receptor $\epsilon 1$ subunit. Nature 373:151-155.

Saucier D, Cain DP (1995) Spatial learning without NMDA receptordependent long-term potentiation. Nature 378:186-189.

Seeburg PH (1993) The molecular biology of mammalian glutamate receptor channels. Trends Neurosci 16:359-365.

Sprengel R, Suchanek B, Amico C, Brusa R, Burnashev N, Rozov A, Hvalby O, Jensen V, Paulsen O, Andersen P, Kim JJ, Thompson RF, Sun W, Webster LC, Grant SG, Eilers J, Konnerth A, Li J, McNamara JO, Seeburg PH (1998) Importance of the intracellular domain of NR2 subunits for NMDA receptor function in vivo. Cell 92:279-289.

Tsien JZ, Huerta PT, Tonegawa S (1996) The essential role of hippocampal CA1 NMDA receptor-dependent synaptic plasticity in spatial memory. Cell 87:1327-1338.

Watanabe M, Inoue Y, Sakimura K, Mishina M (1992) Developmental changes in distribution of NMDA receptor channel subunit mRNAs. NeuroReport 3:1138-1140.

Watanabe M, Inoue Y, Sakimura K, Mishina M (1993) Distinct distributions of five $N$-methyl-D-aspartate receptor channel subunit mRNAs in the forebrain. J Comp Neurol 338:377-390.

Watanabe M, Fukaya M, Sakimura K, Manabe T, Mishina M, Inoue Y (1998) Selective scarcity of NMDA receptor channel subunits in the stratum lucidum (mossy fiber-recipient layer) of the mouse hippocampal CA3 subfield. Eur J Neurosci 10:478-487.

Yagi T, Tokunaga T, Furuta Y, Nada S, Yoshida M, Tsukada T, Saga Y, Takeda N, Ikawa Y, Aizawa S (1993) A novel ES cell line, TT2, with high germline-differentiating potency. Anal Biochem 214:70-76.

Yamazaki M, Mori H, Araki K, Mori KJ, Mishina M (1992) Cloning, expression, and modulation of a mouse NMDA receptor subunit. FEBS Lett 300:39-45. 